\title{
Peer observation helping professional development
}

\section{Peter Russell}

\author{
Visiting Faculty, Asia University
}

This paper sets out the author's ideas of how peer observation can be a useful tool for teachers of English as a Second Language (ESL), especially when teaching as part of a large faculty. He will demonstrate how observing other teachers' classes can stimulate and improve the professional development of the observing instructors. He will argue that the simple act of observing other methods of teaching need not be in any way a challenge to the teachers' positions but rather, a helpful and encouraging element in the career of the instructor.

本論では、教師同士の授業を観察することが、特に大きな学部の中で ESLを教える教師にとって役立つ手段となることを述べる。他の教師の 授業を観察することで、観察している教師の専門的な成長が見られる。 授業を観察することがその教師の負担になることはなく、むしろ教育者 としてのキャリアにとって強みになることを論じる。

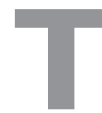

his paper will set out my ideas of how peer observation can be a useful tool for teachers of English as a Foreign Language (EFL), especially when teaching as part of a large faculty. I will demonstrate how observing other teachers' classes can stimulate and improve the professional development of the observing instructors, and argue that the simple act of observing other methods of teaching need not be in any way a challenge to the teachers' positions but rather, a helpful and encouraging element in the career of the instructor.

My first proposal is that we, as teachers, should always take steps to improve our teaching methods. I propose that we interrogate our teaching profession-through peer observation-not like a pupil, but like a judge. We can do this by reflecting on what we see both in those observations, and then again through post observation meetings with our fellow colleagues.

Peer observations can make any class more effective for students through enriching the experience of instructors while, at the same time, aiding the professional development of the teachers involved. Helping achieve better lessons

\section{SIG Spotlight: PALE SIG}

全国語学教育学会
The Japan Association for Language Teaching (JALT)
PALE 特別分科会
'Professionalism. Administration and Leadership in Education'"
Special Interest Group (SiG)

The JALT PALE SIG's mission starts in raising awareness about issues that affect language teachers inside as well as outside the classroom, through PALE Newsletter and website $<$ jalt.org/groups/PALE $>$.

PALE also has an online forum for teachers to connect with one another about important issues that arise and affect foreign teachers in Japan.

PALE welcomes submissions on the following broad range of topics which include professional development and evaluation, sociological trends in education, professional ethics, politics and philosophy of education, administration and management, employment conditions, leadership dynamics, legal issues and human rights, comparative education, globalization and foreign language teaching, curriculum design, implementation and maintenance, and the demands societies place on educators.

Potential contributors to the PALE newsletter are invited to contact the publications officer, Brooks Slaybaugh at <slaybaugh05446@yahoo.com>.

while at the same time improving teachers' professionalism is something all institutes of learning can approve of.

If we open a dictionary the definition of profession is pretty straightforward;

"A vocation or calling especially one that involves some branch of advanced learning or science" (Thompson, D. 1995).

There can be genuine professional development through peer observations. Our teaching values will change the more interaction we have with different teachers and their classes. If we admit that, as teachers, we gain valuable insight into teaching through attending conferences and seminars, which are, at best, a semi-annual occurrence, then surely it must be to our benefit 
to have a more regular opportunity of engaging with our fellow colleagues that we work with on a daily basis. If the theory that going to conferences and subscribing to ESL journals is good for professional development, then surely we can say the same for peer observations. Surely this is one way to inspire personal change.

Attending conferences and such, we must, obviously, take things on trust from the presenters regarding their experiences. Presumably though we are still somewhat sceptical; it is impossible to investigate everything personally. Checking everything would take far too long. The growth of EFL experience depends on being able to build on the work done by others. Peer observations would seem ideal in this regard. I think it much easier to believe what we see with our own eyes; we can revise our opinions in the light of what we see before us. This is a much stronger learning experience than merely accepting information verbatim from journals, books, and conferences.

In the standard, accepted concept of peer observation, teachers (i) meet to discuss what will happen during the observation, (ii) observe each other in their classrooms as they teach, and (iii) hold a post observation meeting to share opinions. It is a three-part cycle: pre-observation discussions, an observation, and then postobservation feedback (Wilkinson, 2001, p. 25).

Taking the fear out of the peer observation process is a worthy and necessary objective. It should be voluntary, ideally it should be reciprocal, and thirdly the observing teacher should reflect and focus on what he/she has learned from the lesson, rather than offering suggestions to the observed. This, I think, is the principal difference between my proposal and the standard, accepted definition of peer observation. By putting the onus on the observing teacher the instructor giving the lesson has nothing to fear in any post lesson discussions. During the observation, the observer's job is not to decide if the teacher is teaching well or not but rather what they, as observers, can learn and implement for their own classes.

My proposal here is that the observed teacher can decide that he/ she does not want any information garnered by the observer. The process should be completely open and transparent with nothing being done to make either party uncomfortable.

After the observation comes valuable postobservation feedback. Here I think it best if the observer merely facilitates the teacher's exploration of any questions that arise-and hopefully finding some answers, if asked. I think it quite permissible that the observing teacher use what he/she has seen to reflect only on his/her own lessons. The observed and not the observer should determine the direction and pace of these discussions; to use a rather American phrase, the observed teacher should feel a sense of ownership of the process.

Feedback, if indeed asked for, should be based firmly on the actual events in the classroom, and not on the observer's opinion of appropriate teaching practice.

The potential of peer observation as a reflective professional development tool, a personal lowtech way of incorporating reflective practice into day-to-day classroom teaching, has long been underestimated.

As stated earlier, teachers of English may enhance their professional competence by participating in professional development programs such as workshops, seminars, and conferences. These programs however seem less than adequate. Firstly, such programs are rare, and so not all teachers of English get the opportunity to participate in them. Secondly, the approach of these programs is based on the applied science model according to which experts convey findings of scientific knowledge and experimentation to classroom teachers, and it is up to the teachers to put this received knowledge into practice. Surely a more reflective approach, through peer observation, makes the knowledge more accessible to practice for the teacher and easier to understand for the students. Indeed if peer observation poses questions as to what exactly the role of the teacher is in the classroom, this can be no bad thing.

"The whole notion of teacher as disseminator of knowledge is now turned on its head. While in the old scenario, the teacher was the boss, in the new scenario, the teacher becomes facilitator. The teachers, who employ knowledge in the classroom, do not funnel information into their student's heads. The teacher is no longer the sage on the stage, but the guide on the side becoming less central to the learning process." (Akhtar Siddiqui, 2002, p.13) The teacher is considered as a researcher (Stenhouse, 1975), a reflective practitioner (Schon, 1983), a decision maker (Reagon, 1993), and even as a strategist (ibid, p. 189).

In this fast changing global scenario, peer observation is a useful tool in becoming a better 
instructor. It is a pretty simple process because it is teacher-initiated and teacher-directed: it involves teachers observing colleagues, collecting data about their classrooms and their roles within them, and using the data as a basis for their own self-evaluation (Richards and Lockhart, 1994). Through observation the observer constructs his/her own theories of teaching, drawing on knowledge, skills, training and experience, as well as all that is learned from the classes observed.

We have seen how professional development can progress through peer observation. These observations do not need to be in any way confrontational. I suggest in fact the very opposite-they should be used by the observing teacher as an opportunity to reflect on his/ her own classes and, in this way, experience is gained. It's a win-win scenario. The observing teacher gains insights that would otherwise not be available while the teacher can gain feedback if that is what she/he desires. There is no pressure from, or on either side.

In conclusion then we can see how peer observation helps the professional development of those teaching in a profession that is pretty solitary once that classroom door closes. The sharing of experience and knowledge through peer observation is an ideal opportunity to open up the classroom and take the mystique away from what goes on there; it dilutes the idea of a teacher disseminating wisdom from the top. If we have indeed become facilitators, facilitating students on their quest to learn, surely we should equally be facilitators towards our fellow colleagues on their own quest in search of experience and knowledge. When a great lesson is observed it is, I think, the duty of the observer to try to implement the energy and intelligence of that instruction. Salutary to observe: but better still to emulate.

\section{References}

Akhtar Siddiqui, M. (2002). Faculty development for excellence in higher education. Madrasa India: University News.

Reagon, T. (1993). Educating the reflective practitioner: The contribution of philosophy of education. Journal of Research and Development in Education, 26(4), 189-196.

Richards, J. C., \& Lockhart, C. (1994). Reflective teaching in second language classrooms. Cambridge: Cambridge University Press.
Schon, D. A. (1983). The reflective practitioner: How professionals think in action. New York: Basic Books.

Schon, D. A. (1987). Educating the reflective practitioner. San Francisco: Jossey-Bass.

Stenhouse, L. (1975). An introduction to curriculum research and development, London: Heinemann Educational.

Thompson, D. (Ed.). (1995). Oxford English Dictionary ( $9^{\text {th }}$ ed.) London: Oxford University Press.

Wilkinson, R. (2001, September). What's the good of an EAP/ESP professional? IATEFL ESP SIG Newsletter, 20, 25-30.

This essay first appeared in the PALE Newsletter (Special Interest Group of the Japan Association for Language Teaching) XII vol. 1, pp. 2-9. For this publication, it was revised.

Peter Russell is a native of Limerick, Ireland and has a BA and MA in French, from the University of Limerick, as well as a PGCE in French and German from the University of Christchurch (United Kingdom). He has worked in Germany, Belgium, France, Australia, Turkey and the United States before first coming to Japan in 1999. Married to Mayumi, with two children, Erika and Mike, he lives in Suginami-ku, Tokyo. Hobbies are swimming and watching Irish rugby teams take on, and beat the world. He can be contacted at <prussell@asia-u.ac.jp>.

\section{Raising Bilingual Children in Japan}

\section{JALT2013, Kobe Convention Center, Portopia Kobe}

The JALT Bilingualism SIG and Kobe JALT Chapter present a talk on the basics of raising children in two or more languages in Japan. Join speaker Mary Nobuoka, Bilingualism SIG coordinator, in Kobe on Sunday, October 27, 2013 from 11:30 in the Tsutsuji room. 